\title{
Seismic hazard in low slip rate crustal faults, estimating the characteristic event and the most hazardous zone: study case San Ramón Fault, in southern Andes
}

\author{
Nicolás P. Estay ${ }^{1,2,3}$, Gonzalo Yáñez ${ }^{1,2,3}$, Sebastien Carretier ${ }^{4,5,6,7}$, Elias Lira ${ }^{1}$, and José Maringue Me $^{1,2}$ \\ ${ }^{1}$ Pontificia Universidad Católica de Chile, Santiago, Vicuña Mackenna 4686, Chile \\ ${ }^{2}$ CIGIDEN, Santiago, Vicuña Mackenna 4686, Chile \\ ${ }^{3}$ CEGA, Universidad de Chile, Beauchef 850, Santiago, Chile \\ ${ }^{4}$ IRD, UR 234, GET, 14 avenue E. Belin, 31400, Toulouse, France \\ ${ }^{5}$ Université de Toulouse, UPS, GET, 14 avenue E. Belin, 314000, Toulouse, France \\ ${ }^{6}$ CNRS, GET, 14 avenue E. Belin, 314000, Toulouse, France \\ ${ }^{7}$ Departamento de Geología, FCFM, Universidad de Chile, Beauchef 850, Santiago, Chile
}

Correspondence to: Nicolás P. Estay (nnperez@puc.cl)

Received: 13 January 2016 - Published in Nat. Hazards Earth Syst. Sci. Discuss.: 9 March 2016

Revised: 2 November 2016 - Accepted: 3 November 2016 - Published: 30 November 2016

\begin{abstract}
Crustal faults located close to cities may induce catastrophic damages. When recurrence times are in the range of 1000-10000 or higher, actions to mitigate the effects of the associated earthquake are hampered by the lack of a full seismic record, and in many cases, also of geological evidences. In order to characterize the fault behavior and its effects, we propose three different already-developed timeintegration methodologies to define the most likely scenarios of rupture, and then to quantify the hazard with an empirical equation of peak ground acceleration (PGA). We consider the following methodologies: (1) stream gradient and (2) sinuosity indexes to estimate fault-related topographic effects, and (3) gravity profiles across the fault to identify the fault scarp in the basement. We chose the San Ramón Fault on which to apply these methodologies. It is a $\sim 30 \mathrm{~km} \mathrm{~N}-\mathrm{S}$ trending fault with a low slip rate $\left(0.1-0.5 \mathrm{~mm} \mathrm{yr}^{-1}\right)$ and an approximated recurrence of 9000 years. It is located in the foothills of the Andes near the large city of Santiago, the capital of Chile (>6000000 inhabitants). Along the fault trace we define four segments, with a mean length of $\sim 10 \mathrm{~km}$, which probably become active independently. We tested the present-day seismic activity by deploying a local seismological network for 1 year, finding five events that are spatially related to the fault. In addition, fault geometry along the most evident scarp was imaged in terms of its electrical resistivity
\end{abstract}

response by a high resolution TEM (transient electromagnetic) profile. Seismic event distribution and TEM imaging allowed the constraint of the fault dip angle $\left(\sim 65^{\circ}\right)$ and its capacity to break into the surface. Using the empirical equation of Chiou and Youngs (2014) for crustal faults and considering the characteristic seismic event (thrust high-angle fault, $\left.\sim 10 \mathrm{~km}, M_{\mathrm{w}}=6.2-6.7\right)$, we estimate the acceleration distribution in Santiago and the hazardous zones. City domains that are under high risk include the hanging wall zone covered by sediments and narrow zones where the fault could break the surface. Over these domains horizontal PGA can be greater than $0.5 \mathrm{~g}$ and eventually produce building collapse.

\section{Introduction}

In active margins, sustainable balance between city development and geological environment requires understanding seismic hazard to reduce the associated risks. When city emplacements are adjacent to potentially active crustal faults, seismic risk are elevated; thus, it is important to quantify their possible effects. A good example to demonstrate the potential danger of crustal faults is the Chūetsu earthquake of $M_{\mathrm{W}}=6.6$ in Japan in 2004. Japan has high standards of antiseismic norms and therefore the expected damage in a given 
event is low. Nevertheless, 48 deaths and 5000 houses destroyed or with important damage were reported (Scawthorn and Rathje, 2006). Considering only the last decades, several catastrophic crustal events have been reported, affecting human lives and infrastructure. Some examples are the Nepal earthquake of $M_{\mathrm{w}}=7.8$ on 25 April 2015, with more than 8000 deaths and 17000 wounded (USGS, 2015); and the $M_{\mathrm{w}}=6.2$ earthquake on 26 January 1985 in Mendoza, Argentina, in the Andes, with six deaths and more than 12500 constructions destroyed (USGS, 2016). The previous account motivates the development of the best possible knowledge to mitigate the seismic risk associated with crustal faults that are found near highly populated cities. This assessment is simpler when fault rates are high or a large earthquake happens in instrumental or historically recorded times. Assessment is more difficult when none of these conditions are met. An example of this case is the San Ramón Fault (SRF) in the southern Andes (Fig. 1), located in the foot hills of Santiago, the highly populated capital of Chile (>6000000 inhabitants) (Armijo et al., 2010; Farías et al., 2008; Rauld et al., 2006; Vargas et al., 2014). We chose this case for the high potential risk associated with it and for the chance to propose and test an integrated methodology to estimate seismic hazard.

Defining whether or not the fault is active is crucial in affirming that the risk exists. An active fault that is preferentially oriented with respect to the current tectonic regime allows stress release, eventually triggering earthquakes (examples of preferentially oriented faults are normal and trust faults subject to Andersonian stress regime (Anderson, 1951), with a strike perpendicular to $\sigma_{3}$ and sigma $\sigma_{1}$, respectively). Since the lack of seismic events does not necessarily imply fault inactivity, seismic recording could suggest an active condition. In order to identify the potential seismic activity of the San Ramón Fault, we deployed a microseismic network of five stations for 1 year. We acknowledge that a definitive answer in this regard requires decades of seismic recording; however, with a 1-year time window we are able to have a first order idea of the fault activity.

Along the SRF, the probable low recurrence of characteristic earthquakes, $\sim 9 \mathrm{ka}$ (Vargas et al., 2014), requires a complementary approach to characterize its geometry and long-term behavior. One important variable in understanding the seismic hazard is the rupture length of a characteristic earthquake. A characteristic earthquake represents a repeating event that accumulates the most important displacement in the fault (Schwartz and Coppersmith, 1984). This model does not necessary fit with all faults and it is not demonstrated for the SRF; however, the use of this concept can be a useful tool for a first order approximation of the seismic hazard. A good strategy to estimate the rupture length is defining some methodologies capable of integrating the fault displacement in time. Consistent with this strategy, we consider the following methodologies:
1. the stream gradient index, which can compare the relative uplift rate in a certain area by studying the topographic profile of near-fault rivers (e.g., Font et al., 2010; Casa et al., 2010);

2. the sinuosity index, which estimates the uplift of a fault by observing the sinuosity of the mountain front (Bull and McFadden, 1977);

3. across-fault gravity profiles to estimate the shape of the fault scarp in the basement beneath the sedimentary basin, given the large density contrast between rocks and sediments, and also because basement morphology is a useful marker of cumulative faulting.

Since the SRF has a low slip rate, fault scarp morphology may be modified by deposit and/or erosion surface processes. Thus, we favor the use of gravity profiles and geomorphological measurements instead of scarp topographic analyses. To develop the geomorphological methodologies, we used a $30 \mathrm{~m}$ resolution DEM (SRTM30; Farr et al., 2007), and for gravity we used a Scintrex CG-5 Autograv gravity meter and an R4 Trimble DGPS.

As a final product of this research we tackle the difficult question of relating the occurrence of a given seismic event with an associated damage prediction. One possibility is to estimate the expected acceleration during a characteristic earthquake, and then link this output with damage. Acceleration is an objective measure of the seismic effects, and thus it is not affected by the quality of the housing or infrastructure. We chose empirical equations for crustal earthquakes (e.g., Sadigh et al., 1997; Chiou and Youngs, 2014) to predict the peak ground acceleration (PGA). The robustness of this methodology is grounded in the last decade of understanding of the key variables that control the PGA. Principal variables are event magnitude, fault type, hanging wall, and site effects (near field effects). We chose the Chiou and Young equation (2014) because this model also accounts for a low slip rate crustal fault, and has an extensive record of different earthquakes worldwide. In order to use this particular approach, further parameters are required, such as the shallow depth of the rupture and the dip of the fault. We estimated these parameters with a joint interpretation of the surface geology (Armijo et al., 2010; Rauld, 2011; Vargas et al., 2014), the results of the microseismic study, and a high-resolution 2-D geo-electrical TEM study.

\section{Geological settings}

This region has been dominated by the subduction of the Nazca Plate underneath the South American Plate since at least the Jurassic time (Mpodozis and Ramos, 1989). Upper basement rocks are dominated by the volcanosedimentary Abanico and Farellones formations. These 


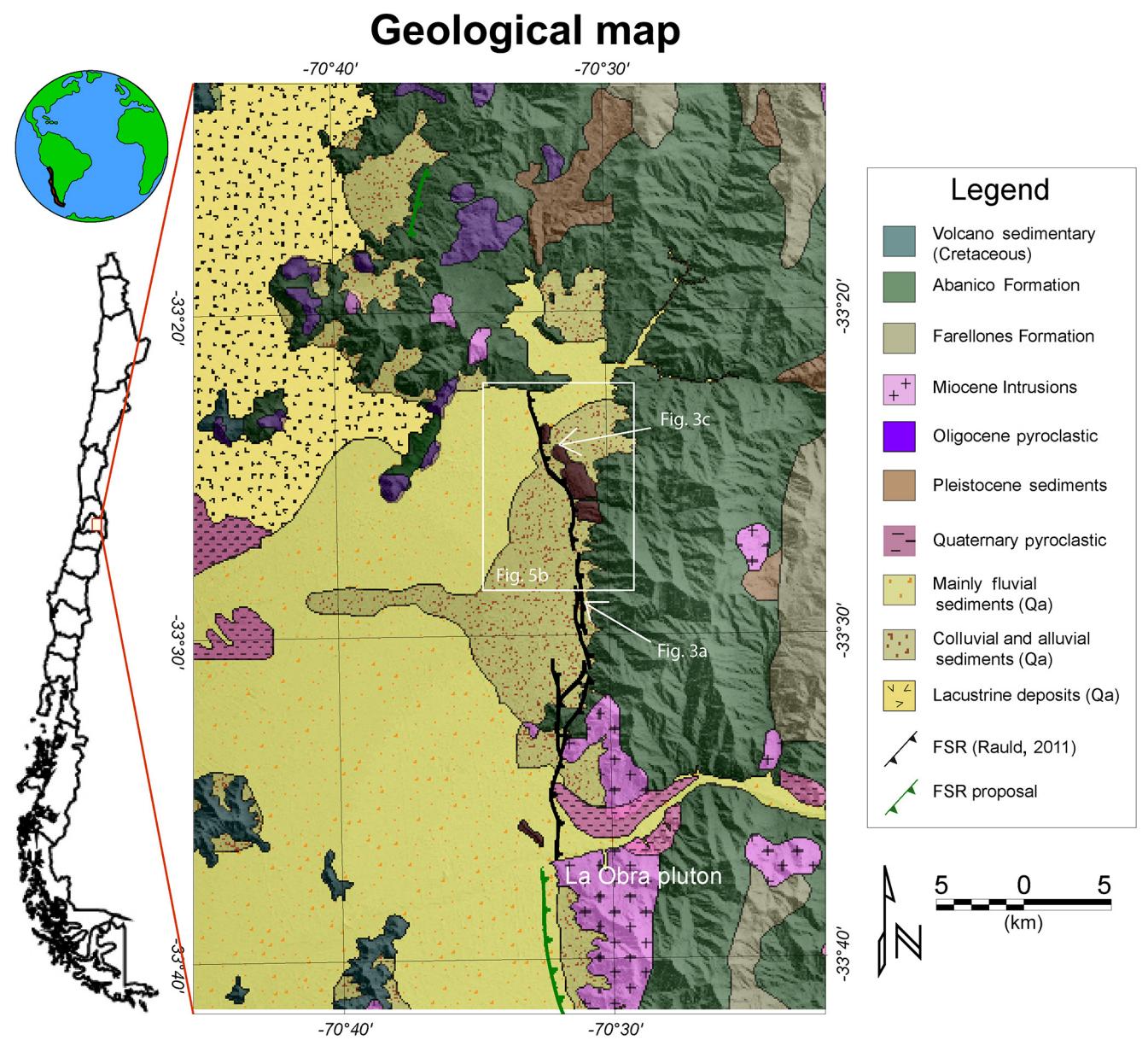

Figure 1. Geological map of the zone (Thiele, 1980; Fernández, 2003). In the figure the location of the Apoquindo hill outcrop (Fig. 3c) and the TEM profile can be observed (Fig. 3a).

volcano-sedimentary sequences are mainly constituted by pyroclastic and lava strata, interdigitated with lava and different sedimentary rocks. The earliest Abanico Formation was deposited during the late Eocene-Oligocene and was reformed later on (Charrier et al., 2002; Godoy et al., 1999). The Farellones Formation was deposited above the underlying sequence during the early and middle Miocene (Charrier et al., 2002). These volcano-sedimentary sequences are also intruded upon by Miocene plutons (Kurtz et al., 1997; Thiele, 1980). Among them, we find the La Obra pluton $19.6 \pm 0.5 \mathrm{Ma}$ (Kurtz et al., 1997), emplaced in the foot hills of the Andes near the SRF (Thiele, 1980).

The Santiago Basin sediments can be grouped into four main sequences. The widespread and well-compacted fluvial sediments, associated with the material transport along the Maipo and Mapocho rivers (i.e., Leyton, 2010; Yañez et al., 2015). In addition there are the alluvial and colluvial deposits, which are semi-compacted and spatially concentrated in the piedmont of the Andes (Fernández, 2003). Finally, and restricted to the northern area of the study, it is possible to find fine soil, mostly lacustrine deposits, and to a lesser ex- tent in the western and southern area of the study, pyroclastic ash related to the Maipo volcanic eruption $\sim 450000$ years ago can be found (Stern et al., 1984).

The San Ramón Fault has been studied using highresolution DEM, satellite images, and field observations (Armijo et al., 2010; Rauld, 2011). These authors conclude that the SRF is a west-verging reverse fault that accommodates the compressive stress regime in this segment of the central Andes (see Fig. 1). One of the best outcrops from which to observe the fault can be examined in Fig. 3c. The ignimbrite of the Maipo eruption $\sim 450000$ years ago allows a rough estimation of fault slip rate, considering that these deposits are preserved in the hanging and foot walls. The offset of $60 \mathrm{~m}$ determines a minimum slip rate of $0.13 \mathrm{~mm} \mathrm{yr}^{-1}$ (Armijo et al., 2010). A paleo-seismological study on one trench (Vargas et al., 2014) identifies two events in the last $17-19 \mathrm{ka}$ with a cumulative displacement of $9.7 \pm 1.2 \mathrm{~m}$, considering the fold of the layers (the error range is related to an uncertain initial thickness of the layer displaced for the fault). The mean slip rate of the two events is 0.45 $0.64 \mathrm{~mm} \mathrm{yr}^{-1}$, with a recurrence time of $9 \pm 0.5 \mathrm{ky}$ for char- 
acteristic earthquakes (the recurrence error range is related to the mean residence time radiocarbon $\left({ }^{14} \mathrm{C}\right.$ MRT) uncertainty). A maximum earthquake magnitude has been discussed in the range of $M_{\mathrm{W}}=6.3-7.5$ (Armijo et al., 2010; Pérez et al., 2014; Rauld, 2011; Vargas et al., 2014). Differences in the estimated magnitude are a function of the number of fault segments that might be activated synchronically and the fault width. If the segments $\left(\sim 15\right.$ by $\left.15 \mathrm{~km}^{2}\right)$ become active independently, they can generate a $M_{\mathrm{w}}=6.6-$ 7.0 earthquake, while the simultaneous activation of all segments (listric fault of 30 by $30 \mathrm{~km}^{2}$ ) would produce a seismic event of $M_{\mathrm{w}}=6.9-7.4$ (Armijo et al., 2010). Until now, the seismic hazard analysis has only considered this worstcase scenario (Pérez et al., 2014), neglecting the likelihood of other intermediate options. In this regard, we focus this work on a better definition of the SRF fault segmentation, minimizing the smoothing effect of erosion and deposit processes, and subsequently providing in this way new insights on the most likely characteristic earthquake length.

\section{Methodology}

In order to get an estimate of the seismic hazard of the SRF, we consider five steps (see flow chart in Fig. 2). In Sect. 3 we briefly describe these methodological steps, and in Sect. 4 we present the results derived from their application.

\subsection{Present-day fault activity}

To achieve the first goal, we deployed a small seismic network of five borehole seismometers with three-component $2 \mathrm{~Hz}$ sensors (short period S31f-2.0a of IESE) running in continuous mode during a 1-year time window with a sample rate of $100 \mathrm{~Hz}$. The equipment was installed near the fault trace, covering an area of $20 \mathrm{~km}$ by $15 \mathrm{~km}$ (see Fig. 4). The preliminary estimate of the origin times and hypocentral coordinates was determined by means of the HYPOINVERSE program (Klein, 1984), considering the initial velocity model proposed by Villegas (2012) for this area. Then we made a recursive process for the best estimate of velocity structure and event location using the VELEST and HYPOINVERSE code (Kissling et al., 1995). The model with the lowest RMS error has 10 layers and assumes a varying $V_{\mathrm{p}} / V_{\mathrm{s}}$ ratio. The best model was reached after seven iterations.

The association between seismic events and the SRF is determined by the following procedure. Given the SRF surface trace we project its potential extension downwards using an empirical relation (Wells and Coppersmith, 1994). Welllocalized events that are located inside the area of fault influence are considered a likely representation of fault activity. These events were projected onto a central cross section perpendicular to the fault for visual discrimination of truly faultrelated events (see red and blue rectangle in Fig. 4). Comparing the number of events related to the fault with those from

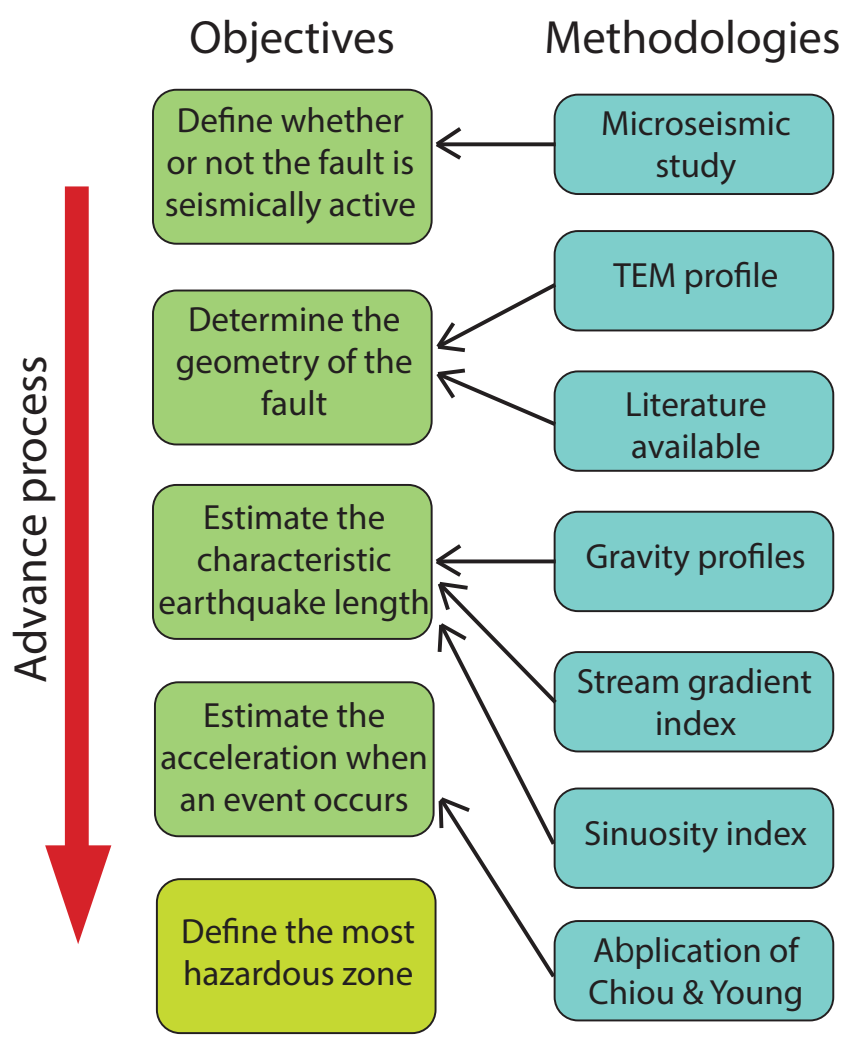

Figure 2. Scheme of objectives and methodologies used in this work. The final objective is in yellow.

other structures, the importance of the fault in the stress release of the whole zone can be discussed. Examples of other structures in the study area are the El Diablo fault, Chacayes back-thrust (Farias et al., 2008), the unnamed faults that fold the Abanico and Farellones units (Armijo et al., 2010; Rauld, 2011), and the structure associated with the "Santa Rosa cluster" (Leyton et al., 2009).

\subsection{Fault geometry, dip and depth of rupture}

To determine the geometrical characteristics of the fault, we consider the data available in the literature (Armijo et al., 2010; Vargas et al., 2014), the spatial distribution of seismic events, and a 2-D resistivity image of a well-maintained scarp. The electrical imaging was obtained by carrying out a high-resolution TEM (transient electro magnetic) experiment that provides a good constraint for the first $150-200 \mathrm{~m}$ fault section. TEM technique is a geophysical method for obtaining an electrical resistivity image of the subsurface (for details of TEM theory and data processing see Telford et al., 1990, for instance). In the field, we used the FastSnap TEM System, completing 24 TEM stations $25 \mathrm{~m}$ apart. To observe the location of the TEM profile see Fig. S1 in the Supplement. For the purpose of getting maximum spatial resolution we use in-loop configuration with a transmitter (Tx) loop of 
$25 \times 25 \mathrm{~m}^{2}$ with 1 and 4 turns and a central receiver loop (Rx) $5 \times 5 \mathrm{~m}$. The receiving coil records the voltage decay for 100 pulses at different sampling rates (frequencies). A stacking for each frequency is performed to reduce noise. Following this procedure a final voltage decay vs. time curve is generated and then modeled and inverted. The inversion is made through iteration of different resistivity and depth models (assuming flat layers) to converge for a solution with an acceptable error (less than $5 \%$ ). The process and the modeling were done with the FastSnap computer software (TEMProcessing 1.1 Model 3.0). A 2-D pseudo-depth section is obtained by gridding the 1-D inversions of each TEM station. This electrical image provides an estimate of the near-surface fault geometry.

\subsection{Rupture length and $M_{\mathrm{w}}$ of the characteristic earthquake}

An empirical first-order relationship between rupture length and earthquake size (Blaser et al., 2010; Wells and Coppersmith, 1994) allows the estimation of the characteristic earthquake magnitude based on a well-constrained rupture length. In this case we use three different methodologies to quantify this length in terms of the associated uplift. Each independent methodology estimates the fault uplift, measuring physical or geomorphologic properties. These methodologies are

1. across-strike gravimetric profiles. Due to the low erosion rate of the basement, tectonic deformation is better preserved in the basement compared to the surface. Density contrast between gravel material and basement rocks makes the gravity method a suitable tool for estimating basement geometry across the fault $\left(\rho_{\text {sed }}=1950 \mathrm{~kg} \mathrm{~m}^{-3} ; \rho_{\text {rock }}=2600 \mathrm{~kg} \mathrm{~m}^{-3}\right.$ from Bosh (2015), consistent with the available values in literature, i.e., Telford et al., 1990). We did 24 gravity profiles across the SRF, with lengths of $2-3 \mathrm{~km}$. We used a sampling distance of $100 \mathrm{~m}$ (in the fault core) and $200 \mathrm{~m}$ (at the flanks) and a distance between profiles of 3 and $8 \mathrm{~km}$ (see profiles location in Fig. 6). We use a Scintrex CG-5 Autograv gravity meter and a Trimble R4 DGPS to measure the gravity and the precise position, respectively. To avoid measurement errors, we eliminated the data with a vertical position error over $30 \mathrm{~cm}$. The mean of the elevation error is $9 \mathrm{~cm}$ with a standard deviation of $7 \mathrm{~cm}(0.027 \pm 0.022 \mathrm{mGal}$ error in free air gravity correction). We used the software ModelVision for the $2.5 \mathrm{D}$ gravity forward modeling. This modeling effort involves the estimation of a second-order regional field to account for the basement heterogeneities and the modeling of the mass-deficiency residual gravity field (for details of the gravity methods and data reduction and modeling see Telford et al., 1990).

2. stream gradient index. This index represents a relative measure of the surface uplift based on drain to- pographic profiles (Hack, 1973; Merritts and Vincent, 1989). Zones with high values suggest larger surface uplift relative to zones with low values (e.g., Casa et al., 2010; Font et al., 2010). This methodology is useful because drainage profiles are good indicators of the long-term uplift process. To determine the corresponding drainage, we used the ArcGIS utilities flow direction, flow accumulation, and watershed. We only chose secondary drainage with similar length to avoid potential bias associated with different scale processes. To calculate the stream gradient (hereafter SL) index we separate the topographic profiles of each drainage into several segments with $50 \mathrm{~m}$ of elevation overlap. For each segment, SL was calculated by multiplying the slope by the middle distance to the drain top (Hack, 1973; Merritts and Vincent, 1989).

3. sinuosity index. Long-term activity of a piedmont fault can be inferred from mountain front sinuosity index (Bull and McFadden, 1977). Low values of this index indicate a fault-controlled landscape (Bull and McFadden, 1977), and the minimum value is 1.00 . This index was developed for normal faults, but it has been satisfactorily proven in reverse faults (Casa et al., 2010; Jain and Verma, 2006; Singh and Tandon, 2007; Wells et al., 1988). At the transition between mountain front (high slope) and basin (low slope), across-strike slope differences generate an anomaly angle. We used ArcGIS to generate a slope map and define the best slope angle that represents the basement-basin contact, comparing the slope map with the most detailed geology information (in this case Rauld, 2011). In the present study, this angle is between 15 and $16^{\circ}$. We separated the fault into different segments where the basement-basin contact shows a constant sinuosity. Then the fault length for each segment was calculated by the geological surface identification available (Armijo et al., 2010). In zones where the fault has not been previously mapped, we propose a straight trace parallel to the mountain front.

Results from each methodology will be discussed separately, and then a joint interpretation will be made to define the rupture length of the characteristic earthquake.

\subsection{PGA field associated with the characteristic earthquake}

Based on the length of characteristic earthquake rupture and fault geometry, we estimate the seismic hazard by calculating the corresponding peak ground acceleration (PGA). In this work we used the attenuation model of Chiou and Youngs (2014), which is appropriate for crustal earthquakes. The PGA field is calculated over a grid of $1 \mathrm{~km}$ spacing. Each grid point is characterized by the associated basement depth and weighted average shear wave velocity for the first $30 \mathrm{~m}$ $\left(V_{\mathrm{S} 30}\right)$, both of which are first-order parameters to quantify 
site effects. We use the basement depth defined by Yañez et al. (2015), while the shear wave velocity is taken from the basin seismic micro-zonation of Leyton et al. (2010). Finally, PGA estimations for each grid point correspond to the maximum PGA among all probable rupture scenarios.

\subsection{SRF seismic hazard in Santiago vs. subduction events}

The hazardous domains derived from the PGA maps are defined in terms of the acceleration distribution. In order to gain some insight into the effects of an SRF event, we compared the expected acceleration estimated in this study with the observed acceleration during the 2010 Chile earthquake in the Maule Region $M_{\mathrm{w}}=8.8$. Assuming that the damages observed are directly related to the PGA, and with minor influence from other variables like the time and length of the earthquake, this comparison provides a simple mechanism for estimating the expected damage for an SRF characteristic earthquake.

\section{Results}

\subsection{Present-day fault activity (seismic study)}

Over the year of microseismic recording we identified 1666 events within a radius of $150 \mathrm{~km}$ around the network. The majority were located on the Nazca-South American Plate contact, and only 245 of them were crustal intraplate earthquakes with a depth above $35 \mathrm{~km}$. Of these crustal earthquakes, $56 \%$ are related to blasts in mining operations, and only the remaining $44 \%$ (110 events) are associated with natural sources. Some events were well registered in only two stations, implying large position errors. To be certain of earthquake locations, we restricted the position errors to $8 \mathrm{~km}$ in both horizontal and vertical coordinates. Well-recorded crustal events are constrained to an $80 \times 100 \mathrm{~km}$ area. The horizontal projection of these seismic events is presented in Fig. 4. We include in this figure two areas that simulate the horizontal projection of two likely fault planes, 30 and $70^{\circ}$. The associated widths were defined by empirical geometrical relationships (Wells and Coppersmith, 1994). In the same figure we include a depth cross section where all the seismic events inside these areas are projected. Some seismic events are associated with a hypothetical high angle fault (60-65 dip, five events), whereas the low angle fault scenario ( $30^{\circ}$ dip) does not fit with the observed seismicity depth distribution.

\subsection{Fault geometry, dip and depth of rupture (TEM)}

The resistivity imaging (Fig. 3) reveals different domains below the well-preserved scarp (the location of the TEM profile can be found in Supplement Fig. S1). Electrical domains are subhorizontal in the first $100-150 \mathrm{~m}$ depth and homoge-
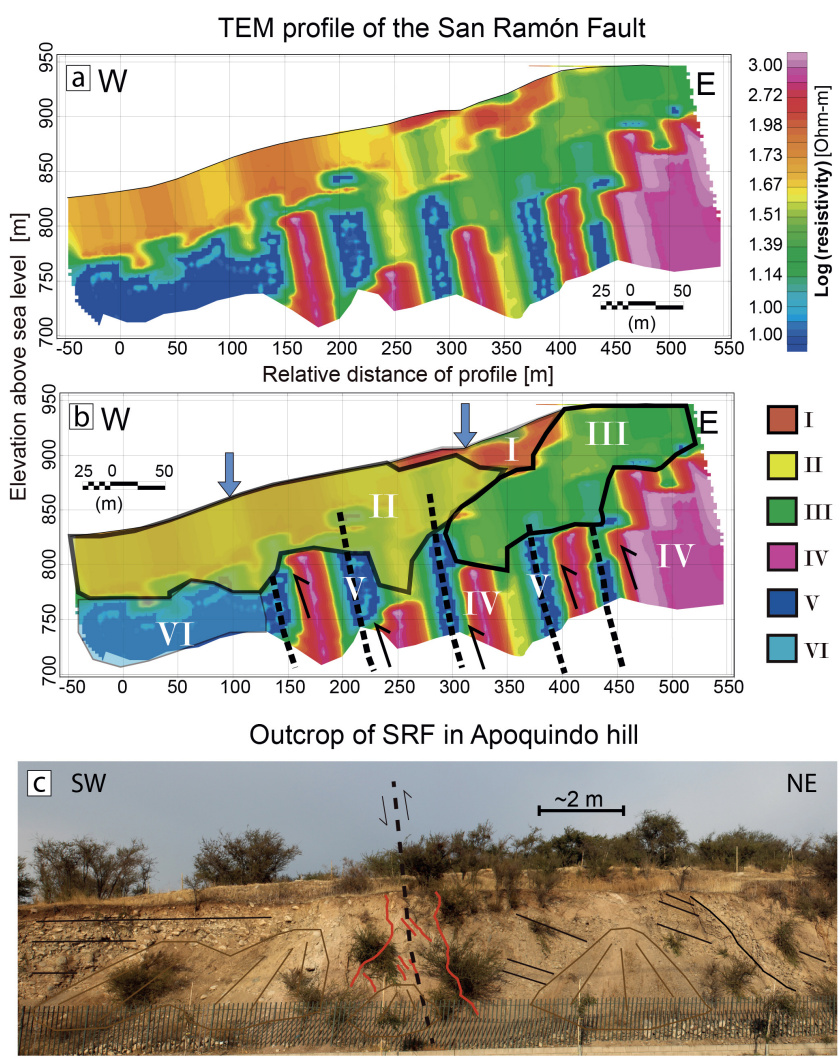

Figure 3. TEM results and the Apoquindo hill outcrop. (a) TEM inversion results. (b) Interpretation of the TEM profile. The blue arrow indicates the fault scarp in surface, and the roman numbers are the different lithologic units described in detail in the Sect. 4.2 TEM results. The location of the profile can be found in Supplement Fig. S1. (c) Apoquindo hill outcrop constituted by quaternary sediments (location in Fig. 1). The continuous black lines represent the dip of the strata. On the SW side, imbricated fluvial sediments show horizontal stratification. On the NE side, we can observe tilting against the natural slope of the sediment strata. This tilting is produced by the SRF, enclosed in the red line, with the reverse kinematic represented by the dashed line in black. The fault cuts quaternary sediments. The colluvial formed by the breakdown clasts is shown in brown. A better-resolution image with a close up of the differences in lithologic units can be found in Supplement Fig. S2.

neous at both edges. But in the fault core, electrical domains are clearly subvertical below $100-150 \mathrm{~m}$ depth. We associate the relative conducting and subhorizontal upper domain with the sedimentary infill of the basin in the foot hills. Below the sedimentary cover we associated the electrical high- or lowresistivity domains with pristine or fracture basement rocks, respectively. In consistency with this observation, it is possible to separate the electrical image into six different units (see Fig. 3b):

i. quaternary high-resistivity sediments at the colluvial wedge of the scarp (mean resistivity of $144 \mathrm{ohm} \mathrm{m}$ ).

ii. quaternary relatively dry sediments $(45 \mathrm{ohm} \mathrm{m})$. 

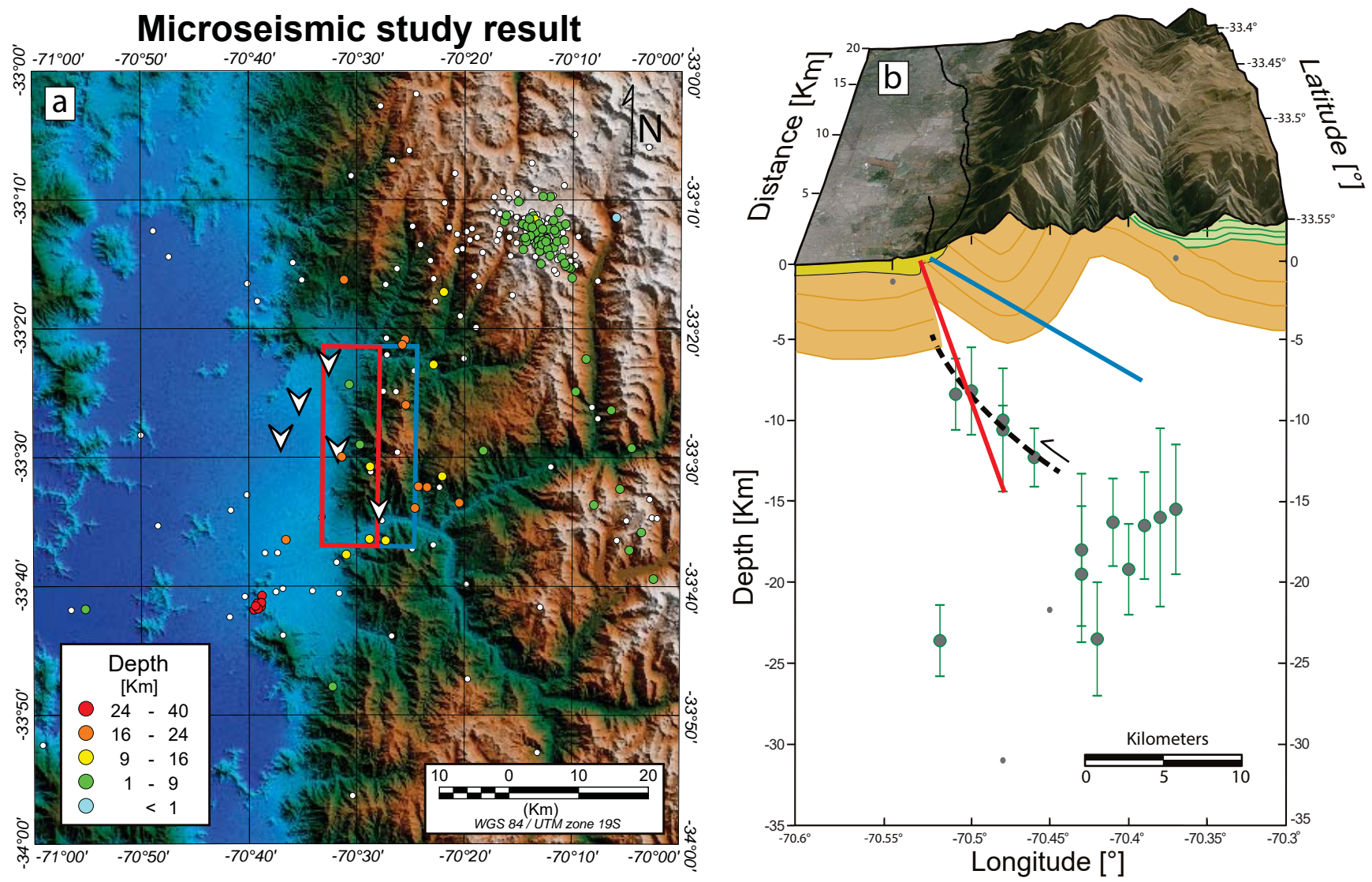

Figure 4. Microseismic study results. In the left panel is the map with epicenters of the recorded events. The color represents depth of the hypocenter. In white are the events with localization errors larger than $8 \mathrm{~km}$. White inverted triangles are the seismic stations. The red rectangle represents the $70^{\circ}$ projection plane on the surface, and the blue rectangle represents the corresponding $30^{\circ}$ projected plane. The right panel shows the seismic profile with well-recorded events (depth error bands in green). The poorly located events are indicated with little grey points without band error. The red and blue lines represent the planes of 70 and $30^{\circ}$, respectively. The dashed black line represents the interpretation of the SRF. The geological projection is based on the first kilometers of the section from Armijo et al. (2010).

iii. upstream quaternary wet sediments in the fault hanging wall $(25 \mathrm{ohm} \mathrm{m})$.

iv. pristine basement rock $(>1000 \mathrm{ohm} \mathrm{m})$.

v. low-resistivity domain associated with fluid percolation along fractured rocks $(1.6 \mathrm{ohm} \mathrm{m})$. In some cases, the resistivity is less than $1 \mathrm{ohm} \mathrm{m}$, probably due to the presence of highly saline hydrothermal fluids that use fault planes as conduits.

vi. unconsolidated sediments interbedded with hydrothermal fluids downstream with respect to the fault (0.5 ohm m).

In terms of the fault geometry, this geoelectrical imaging represents a family of nearly vertical low and/or high resistivity bodies, interpreted as a system of high-angle faults reaching the surface. This suggests that the SRF is a system, not a single fault.

\subsection{Gravity profile}

Gravity modeling demonstrates that cumulative deformation is better expressed in the basement. This behavior is confirmed in the inversion of gravity profiles that cross an evident fault scarp (e.g., Profile 7 in Fig. 5a). The surface scarp observed in the elevation profile (top of Fig. 5a) is less abrupt than the basement scarp observed in the gravity inversion. Basement scarps are characterized by short wavelength $(<200 \mathrm{~m})$ and relatively large $(>10 \mathrm{~m})$ gravity bodies. In addition, the gravity inversion of Profile 7 identifies three scarps in the basement, whereas only two appear at the surface. The erosion process smooths the surface and dilutes the presence of multiple scarps, either by the retreat of previous scarp or as an effect of diffusive erosion (e.g., Carretier et al., 2002).

To understand the along-strike continuity of the basement scarp, and thus the possible rupture length, we mapped all of the basement scarps identified. One example of this scarp continuity analysis is shown in Fig. 5b. In this case we can 


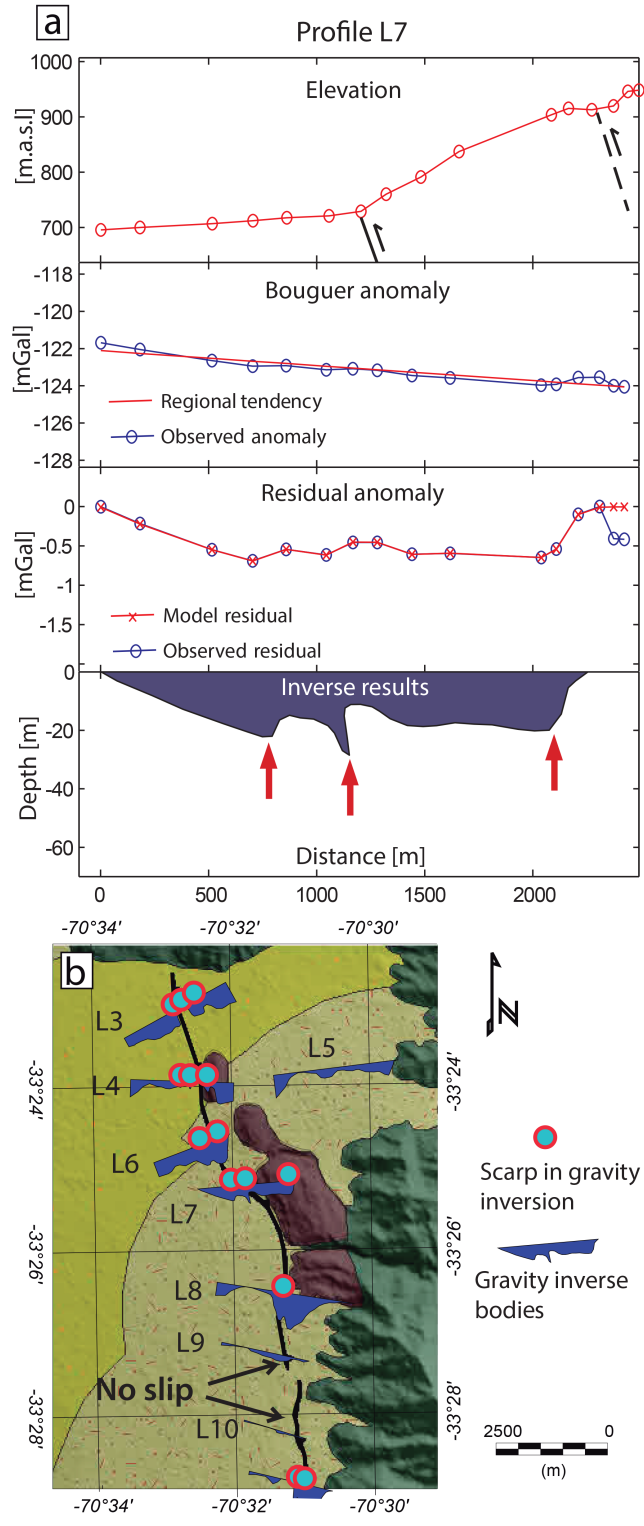

Figure 5. In the upper panel the results of gravity inversion of profile 7 are shown. In the elevation profile the observed surface scarp is drawn (Rauld, 2011). The regional tendency is calculated by a first order approximation. The inverse profile has a vertical exaggeration of $\times 14$, and the red arrow shows the interpreted faults scarp. In the lower panel, the results of profiles 3-10 are shown in planar view. Profiles L5, L9, and L10 do not have evidence of fault scarp in basement.

observe several scarps in N-S strike continuity. Another important measure obtained in the gravity inversion is the accumulated displacement of each profile, which is a complementary approach to estimate the rupture continuity (see Fig. 6c). The accumulated displacement is estimated by the sum of all the basement scarp heights at each profile. Both approaches consistently show scarp discontinuities. Based on this obser- vation we define four different segments with a mean length of $10 \mathrm{~km}$.

\subsection{Stream gradient index (SL)}

The SL only applies to long wavelengths of the topography, with a cutoff that depends on the available stream network, which is much wider than the gravity approach in this particular case. The SL results allow the definition of four main domains (see Fig. 7a) from north to south. The northern one has a concentration of high SL values, with a $\mathrm{N}-\mathrm{S}$ high anomaly ( $\sim 5 \mathrm{~km}$ length) that cuts two drains. The next zone southwards shows low SL values, in addition to the lack of surface fault manifestation. Further south, in the central area where the SRF has been mapped (Armijo et al., 2010; Rauld, 2011), we find a concentration of high SL values consistent with the topographic fault expression. This area of high SL values has a N-S continuity of approximately $\sim 30 \mathrm{~km}$. Finally, at the southern edge we find low SL values coherent with the fault expressions we found that were nonexistent until now.

Lithological differences under the drainage can generate misinterpretation of the SL index as a direct bedrock uplift indicator. Considering that intrusive rocks are less erodible than volcanic rocks $\left(k_{\text {int }}<k_{\text {volc }}\right)$ (Moore et al., 2009; Stock and Montgomery, 1999), the same tectonic uplift in both units would produce a larger surface uplift in intrusive rocks given. In the study area intrusive outcrops show the lowest SL values, evidencing a low surface uplift. This observation validates the use of the SL marker as an estimate of the bedrock uplift, regardless of the lithology in this particular case. To validate our results, we contrast the SL estimate with the approximated erosion rates. Figure $7 \mathrm{~b}$ shows an approximate erosion map of the zone based on the stream potential law (Hack, 1957), taking into account that $k_{\text {int }}<k_{\text {volc }}$. The areas with larger erosion coincide with zones of high SL values. So it is distinguishing, at least in this area, that more SL (surface uplift) means more erosion; therefore, more SL means more bedrock uplift.

\subsection{Sinuosity index (SI)}

Using the sinuosity of the mountain front, seven sections were defined, whose SI values are summarized in Fig. 8. The results of section 6 will not be considered in this analysis because the fault is located outside the piedmont in this section, and thus the methodology is not valid there. Sections 1, 2 , and 4 show values close to $1(1.17-1.43)$, as observed in active reverse faults (1.00-1.50) (Casa et al., 2010; Jain and Verma, 2006; Singh and Tandon, 2007; Wells et al., 1988). The specific sections where SI values are close to 1 also coincide with zones in which gravity profiles suggest fault activity. These sections have a mean value of 1.30 , which reflects the limited capacity of the SRF to shape the mountain front, compared to the 1.04 mean value of the piedmont fault in the Himalayas (Jain and Verma, 2006). Sections 3, 5, 6, and 
Gravity inversion profiles

回
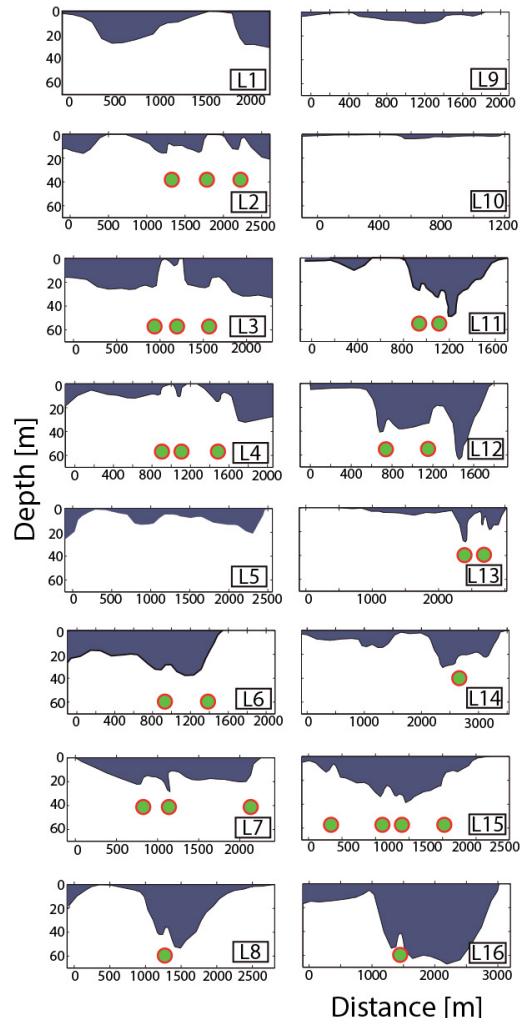
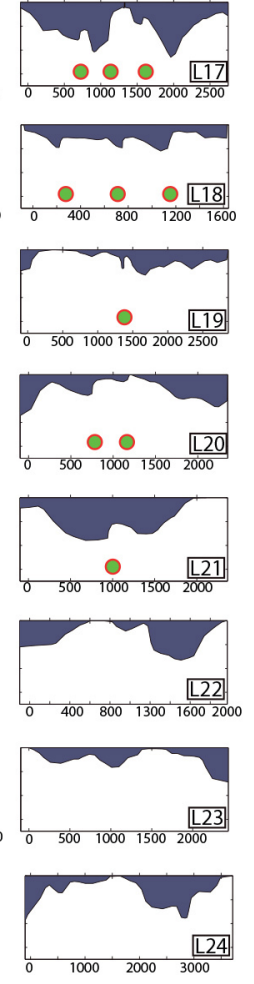

Gravity interpretation
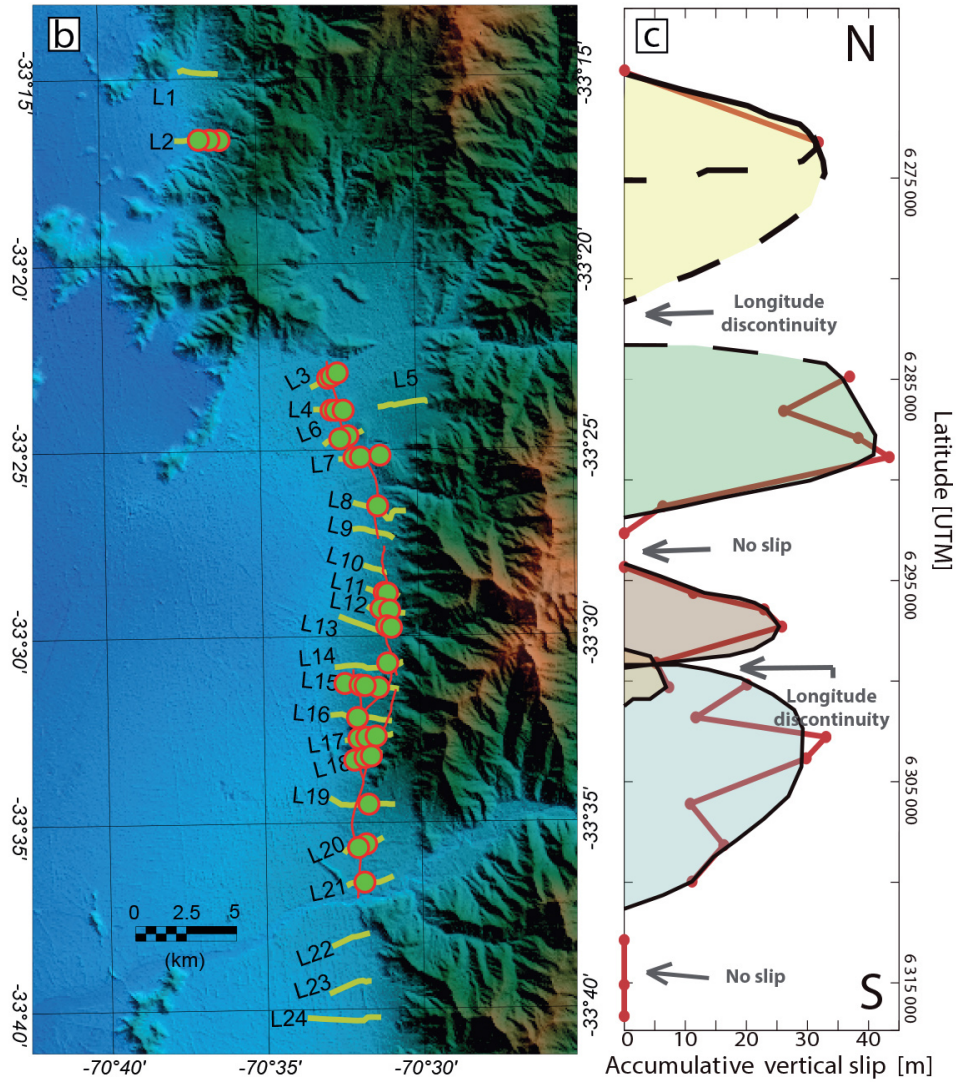

Figure 6. Gravity profile results. (a) In the left panel the gravity profile inversions are shown. The green points represent the observed basement scarp in each profile. (b) In the middle panel the gravity results are shown in planar view. This view allows the fault continuity interpretation to connect to the near spatially related basement scarps. (c) The right panel shows the slip accumulated in each profile as a red line and the interpreted fault segments in different colors. The N-S scale of the middle and right panel are the same.

7 have higher SI values (>2.00). Fluctuating SI values indicate the occurrence of different geomorphologic processes dominating the fault scarp at the surface (i.e., Burbank and Anderson, 2001; Jain and Verma, 2006; Casa et al., 2010).

\subsection{Magnitude of the characteristic earthquake}

The seismic moment magnitude $M_{\mathrm{w}}$ (Eq. 1 from Hank and Kanamori, 1979), can be estimated geologically by the product of the crustal rigidity $(\mu)$, fault slip $(S)$, and the fault area $(L \times W)$ (Eq. 2, Aki and Richards 1980).

$M_{\mathrm{w}}=\frac{2}{3}\left[\log \left(M_{\mathrm{o}}\right)-9.1\right]$

$M_{0}=\mu \mathrm{LWS}$

In this work crustal rigidity is approximated by $3 \times 10^{10} \mathrm{~N} \mathrm{~m}^{-2}$, fault width is estimated in $10-15 \mathrm{~km}$ based on the observed seismicity, and the average slip has been estimated in the range of 1-4 m (Armijo et al., 2010) or using the identified events in the paleo-seismological study $4.8 \pm 0.6 \mathrm{~m}$ (Vargas et al., 2014). In this work we assume an upper bound figure of average slip of $4 \mathrm{~m}$. Regarding the rupture length, gravity modeling, stream gradient index, and the sinuosity results allows for the definition of four fault segments (shown in Fig. 9) that could probably become active independently, as we will discuss in Sect. 5.3. These results also suggest a likely fault extension to the north of the study area, but not southward, at least as a piedmont fault. According to these considerations, the expected magnitude for the characteristic earthquake in any segment would be in the range of $M_{\mathrm{w}}=6.2-6.7$.

\subsection{Empirical model Chiou and Youngs results}

The results shown in Fig. 10a represent the maximum expected PGA in the study area. At each point we choose the largest PGA value from the corresponding rupture of every SRF subfault. Against intuition, the largest acceleration in the northern segment is observed in the footwall block instead of the hanging wall. This can be explained by the infilling of fine sediments (low shear velocity) with larger site effects compared to the basement rocks at the hanging wall. 

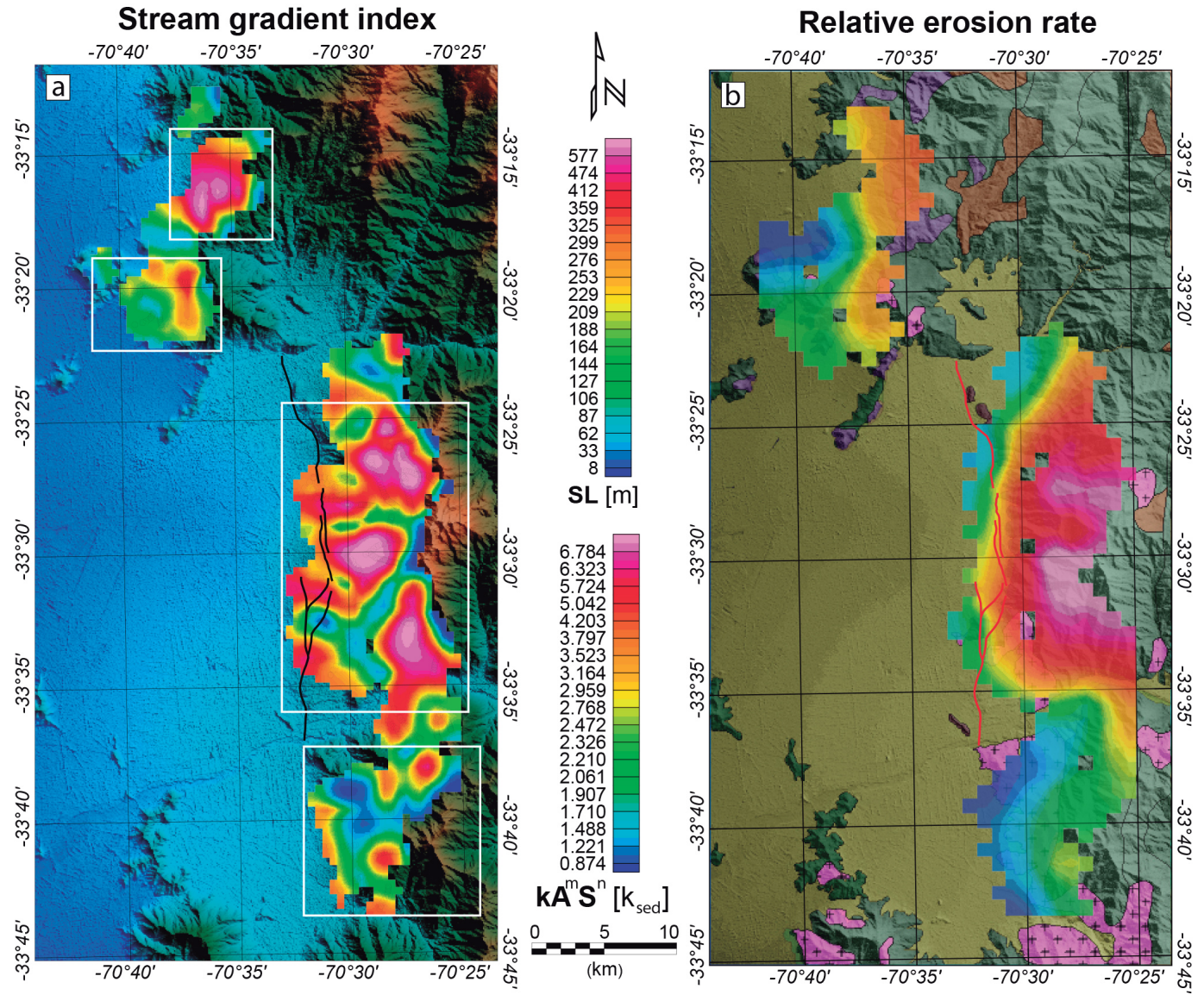

Figure 7. Stream gradient index and relative erosion representation. (a) The stream gradient index results are shown in color. The points represent the middle of each segment where the SL is measured. The different domains that were identified and described in Sect. 4.4 are shown in white rectangles. (b) The relative erosion rates calculated for each drainage with $m=0.28 n=1$, and as-

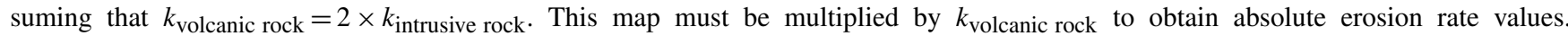
$k_{\mathrm{volcanic}}$ rock $>k_{\text {intrusive rock }}$ is demonstrated for the zone by the knick points related to the intrusive rock in the main Maipo, Mapocho, and Aconcagua rivers (Farías et al., 2008).

In the other segments to the south, as expected, the largest PGA is observed in the hanging wall. In segments 2 and 4, parts of the hanging wall are filled with sediments, generating hanging wall and site effects with PGA values above $0.5 \mathrm{~g}$. The largest acceleration of $0.8 \mathrm{~g}$ shows up in the area already described.

\section{Discussion}

\subsection{Present-day fault activity}

Seismic events spatially associated with the SRF, suggest that the fault is active. If this inference is correct, their depth distribution shows more affinity with a high-angle fault (Fig. 4). This is consistent with the surface expression of the SRF as described by the Apoquindo outcrop and the TEM profile (Fig. 3c). Although reverse fault optimal orientation is low angle, several examples of normal high-angle faults reacti- vated as inverse faults have been described in the Andean orogenesis (e.g., Charrier et al., 2002). Another aspect is the importance of the SRF on the whole stress release of the zone in terms of the seismic productivity. The natural seismicity distribution in the study area indicates that just five events can be related to the SRF, representing $12 \%$ of the 41 well-localized events and $5 \%$ of all 110 crustal events regardless of their location error (but still within the area of interest). This denotes that the San Ramón Fault is not the only structure in the deforming cordillera. Nevertheless, it involves a significant hazard given its likely active condition and its proximity to the city.

\subsection{Fault geometry, dip and depth of rupture}

To estimate the acceleration is necessary to determine some fault first-order geometrical characteristics. Fault type is the first one, and can generate a 0.8 factor to the acceleration for normal faults and 1.3 for reverse ones, with respect to strike 


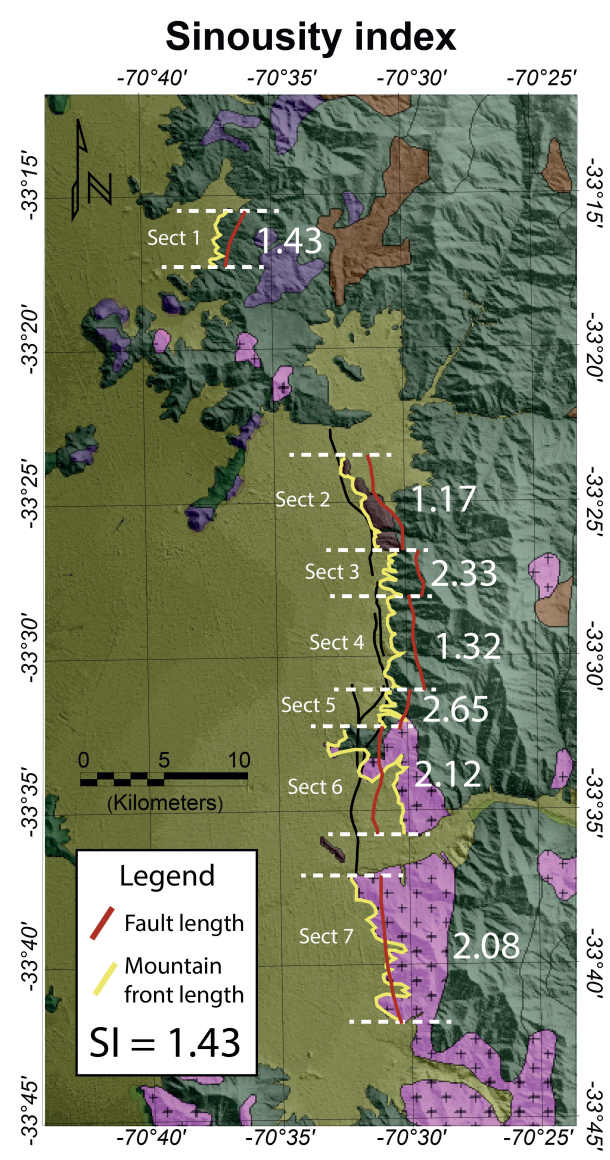

Figure 8. Sinuosity index results. In white the SI values associated with a specific part of the fault named as a section (Sect) in this figure are shown. It is important to note that these sections do not necessarily represent the segments of the fault, they are just a discrete separation along the SRF related to changes in sinuosity in the mountain front. As a reference, the geological map of the zone (Fig. 1) is included in the back.

slip faults (Ambraseys et al., 2005). The TEM profile and the tilting strata in the Apoquindo hill outcrop clearly demonstrate reverse kinematics, which is also well supported by many field observations (Armijo et al., 2010; Rauld, 2011; Vargas et al., 2014). Another relevant variable is the shallow depth of the rupture (Youngs et al., 1997; Chiou and Youngs, 2008). In regard to the SRF, the quaternary sediments in the Apoquindo hill are cut by the fault. Consistent with this observation, TEM results indicate that basement displacement also reaches the basement roof (Fig. 3), and thus breaks the surface. Therefore, the shallow depth of rupture is estimated to be at zero level. The last first-order variable is the fault dip. The NGA-West 2 data indicate a systematical acceleration increasing with larger dips (Chiou and Youngs, 2014). The TEM profile and the Apoquindo outcrop show a nearsurface subvertical plane. At depth the microseismic study is also consistent with a high-angle fault; therefore, the dip angle of the SRF is estimated at $65^{\circ}$. This is consistent with the fold's axial planes eastward from the SRF (Rauld, 2011); see Fig. 4.

\subsection{SRF segmentation}

According to the integrated analysis carried out the SRF is not necessarily a continuous fault along its $\sim 30 \mathrm{~km}$ of $\mathrm{N}-$ $\mathrm{S}$ extension, but rather a segmented one. In this section we discuss the most likely fault configuration. Locations of fault segments are included in Fig. 9.

The northern segment (corresponding to section 1 in Fig. 9) is not necessarily restricted to the length defined in this work because with the information available we cannot trace precise limits. This is mainly because the gravity profiles are a bit sparse. Nevertheless, the existence of the fault in this zone is demonstrated by the stream gradient signal and the gravity profile L2. Despite this drawback, we postulate this segment as a preliminary solution.

In the central area, we propose three segments capable of generating a great earthquake (segments 2, 3 and 4 in Fig. 9) with a high uplift interpreted by the high values of SL and the surface manifestation of the SRF (Armijo et al., 2010; Rauld, 2011). The segmentation of segments 2 and 3 is supported by the gravity profile and the fluctuant sinuosity index and is complemented by lithological changes in the hanging wall unit (see sections 2 and 3 in Fig. 8). In fact, the transition zone between segments 2 and 3 is supported by the lack of gravity signal in the two adjacent profiles (L9 and L10). In addition, the sinuosity index value of 2.33 in this transition zone is much greater than the expected values for active faults. Finally, we observed lower-middle Pleistocene fluvial and alluvial sediments on the hanging wall of segment 2, whereas these deposits disappear southward in segment 3. In segment 3 the hanging wall deposits are middle-upper Pleistocene sediments. This suggests a larger uplift activity in segment 2, capable of preserving older coverage.

To the south, the separation of segments 3 and 4 is mainly argued on the longitude discontinuity of the fault scarps observed on the surface, and on the gravity-derived basement morphology. An example of this discontinuity is represented by the intrusion of the Miocene La Obra granite (Fig. 8). This more competent unit may be responsible for the offset in the rupture plane.

Based on the arguments listed previously, our first-order approximation states that segments 2,3 , and 4 behave as independent ruptures, where each one can generate a similar characteristic earthquake. In addition, the segmentation defined in this work is similar to a first-order approximation with the defined segmentation in a previous work using a topographic analysis (Rauld, 2011).

An important discussion is how independent the rupture of segments 2, 3, and 4, which are separated by less than $3 \mathrm{~km}$, could be. In this scenario it has been suggested that the activation of one segment can trigger the displacement of the adjacent segment (Wesnousky, 2008). However, while this 

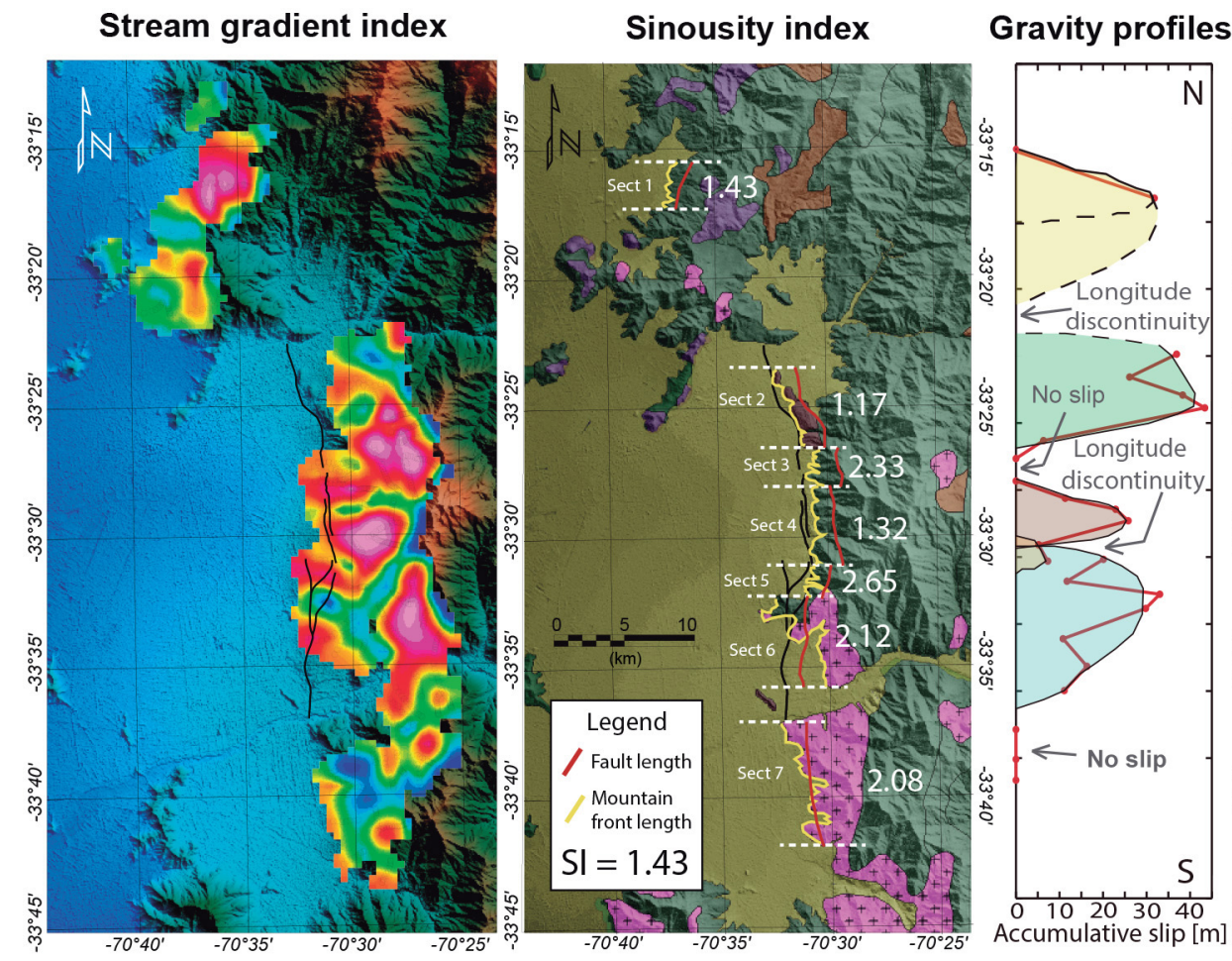

\section{Segment interpretation}

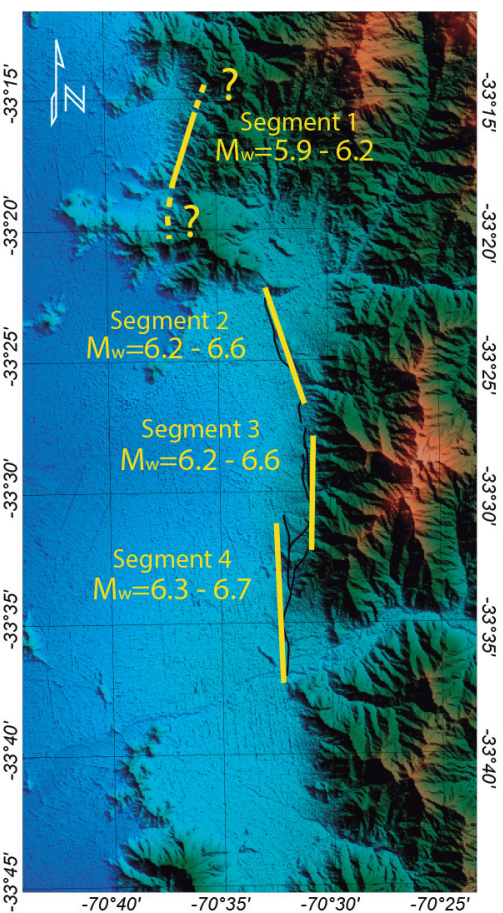

Figure 9. Interpretation of SRF subdomains or segments. It summarizes the results of the three methodologies used to define the length of the characteristic earthquake and the segments interpretation. The northern part of segment 1 has a high value of stream gradient index; additionally it has a low SI value and one gravity profile with $\sim 30 \mathrm{~m}$ of cumulative slip. Segment 2 is spatially related to the central area with high values of stream gradient index. It also has a low SI value and several basement scarps observed in gravity profiles (shown in Fig. 6) with a cumulative slip of $40 \mathrm{~m}$ in mean. Segment 3: separated from segment 2 by high a SI value and without gravity anomalies in two profiles; it presents well-developed surface scarps. Still located in the central high SL index area with a SI value close to 1 and several gravity profiles with basement scarp signature. The TEM profile is also shown here (Fig. 1 and Supplement S1). Segment 4 is separated from segment 3 by a longitude discontinuity. This segment is still located in the central high SL index area and has several gravity profiles with basement scarp signature. The high value of the SI is interpreted by a section where this methodology is not applicable because the fault is not at the piedmont.

behavior is evident in $60 \%$ of cases in strike slip faults, it is not necessarily applicable to reverse faults (Wesnousky, 2008). Some examples of continuous ruptures associated with a specific earthquake are Chi-Chi, Taiwan, 1999 (Chen et al., 2001); Marryat Creek, Australia, 1986 (Machette et al., 1993); Mikawa, Japan, 1945 (Wesnousky, 2008); and El Asnam, Algeria, 1980 (Yielding et al., 1981). In the last case segmented ruptures were formed, but were produced by several events.

In order to discuss the potential activation of several SRF segments, we propose possible scenarios. One possibility is the triggering of a segment given the displacement in the adjacent segment. This case does not imply more hazard because these events are not simultaneous. Another possibility is that at deeper levels the SRF behaves as a single unit, but its stress releases are discontinuous in space at the surface. One example of such a behavior in reverse faults was observed in the Tennant Creek earthquake in Australia. During this earthquake a single event generated a discontinuous rupture at the surface (Crone et al., 1989). According to Crone et al. (1989), this discontinuity was produced by the existence of an alongstrike rupture barrier. Until now there is no geological evidence in the SRF of a rupture barrier like the one identified in the Tennant Creek case. In this regard, our results suggest that deformation is accommodated in several parallel faults that reach the surface. In fact, gravity profiles (Fig. 5) and TEM imaging (Fig. 3) demonstrate the presence of several parallel faults that cut the upper level of the basement, but in some gravity profiles some of these faults do not have an along-strike continuity, suggesting that all of these parallel ruptures stop in those places (see "no slip" places in Figs. 6c and 9). In addition, the observed near-surface displacement has been estimated by means of the time-integration methodologies, gravity modeling, and sinuosity index going back at least $100 \mathrm{ky}$. These observations are not consistent with a continuous and homogeneous displacement along the whole fault trace in a time window ( $>100 \mathrm{ky}$ ) that must involve the occurrence of several characteristic earthquakes. 

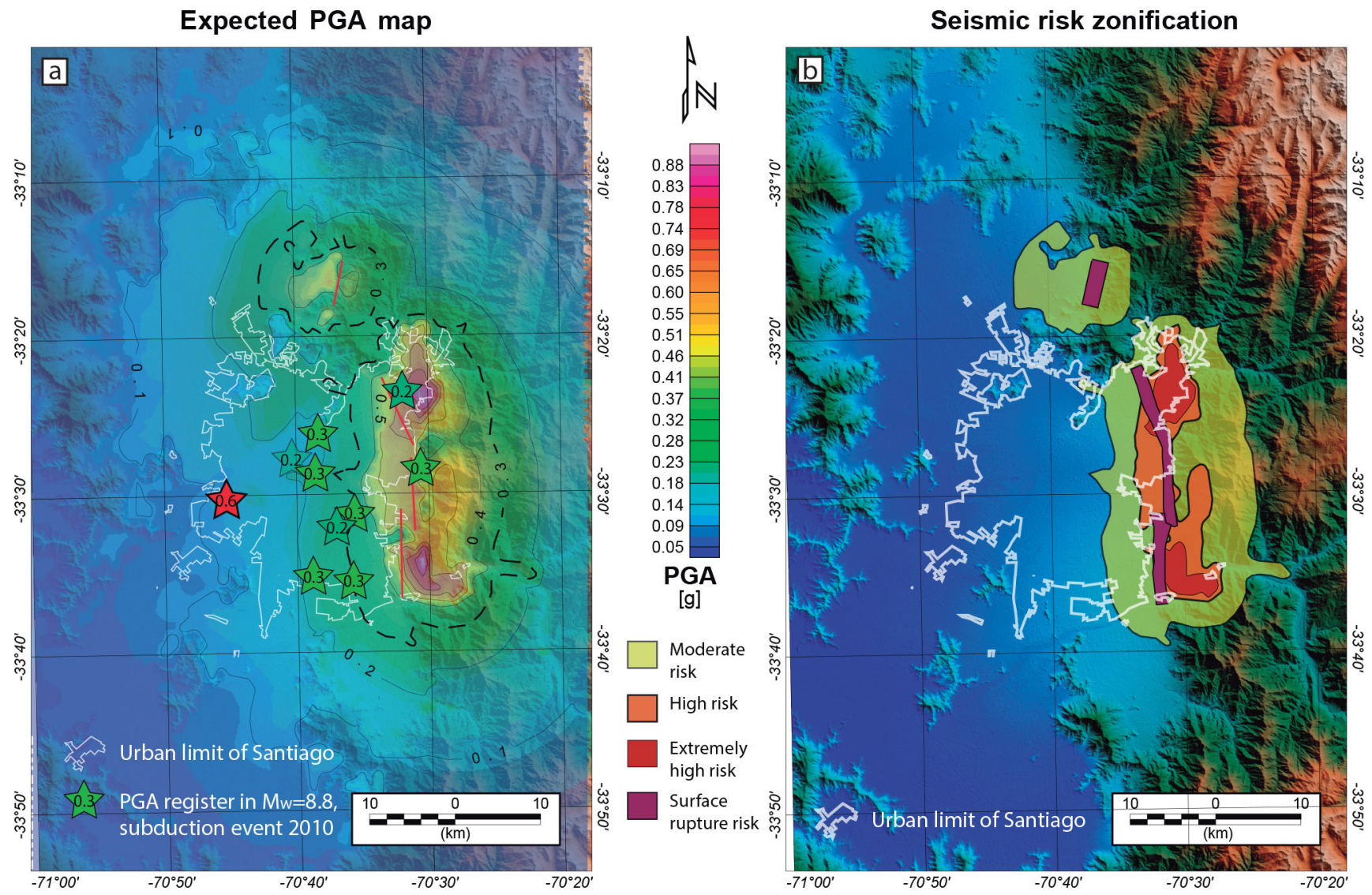

Figure 10. (a) Expected PGA map of the largest acceleration of each point taking into account the four probable rupture scenarios. The stars represent the PGA recorded for the 2010 Maule event $\left(M_{\mathrm{W}}=8.8\right)$ (Barrientos, 2010) in the same color scale. (b) Seismic risk zoning: in yellow the area with acceleration greater than $0.3 \mathrm{~g}$, which is the design PGA estimate by the Chilean norm is shown. In orange the area with more than $0.4 \mathrm{~g}$ is shown. In red the hanging wall filled with sediments that concentrate the greatest PGA $>0.5 \mathrm{~g}$ is shown. In purple the zone with a possible surface rupture, based on the basement scarps identified in gravity profiles is shown.

Although we cannot rule out a single rupture of the whole SRF segment, our evidence consistently favors the occurrence of a single-segment characteristic earthquake with a rupture length of $\sim 10 \mathrm{~km}$.

\subsection{PGA results}

The PGA modeling results are similar to the empirical PGA observed in other reverse earthquakes. Examples of these are the Chūetsu, Japan, $M_{\mathrm{w}}=6.6,2004$ earthquake (Mori and Somerville, 2006); Northridge, California, $M_{\mathrm{w}}=6.7,1994$ earthquake (Porcella et al., 1994); and the Iwate-Miyagi Nairiku, Japan, $M_{\mathrm{w}}=6.9,2008$ earthquake (Cultrera et al., 2013), all with near-epicenter recording stations. The similar PGA suggests that the approximation used in this work is consistent with the empirical evidence.

The range of the PGA values modeled in this work, PGA $>0.3 \mathrm{~g}$ at distances shorter than $10 \mathrm{~km}$ from the fault scarp, are similar to the previous work done at the SRF (Pérez et al., 2014), up to $0.2 \mathrm{~g}$ in the nearby $10 \mathrm{~km}$ from the fault.
Largest values are also similar, PGA $=0.7-0.8 \mathrm{~g}$ (Perez et al., 2014 ) and $0.8 \mathrm{~g}$ in this work. The difference between both results stands on the PGA distribution. In our work we considered the amplification due to sedimentary cover, concentrating larger PGA values at the hanging walls covered by sediments. Whereas in Perez et al. (2014) focus on directional effects, concentrating larger PGA values at the southward fault zone, but neglecting site effects. We are not including directional effects due the lack of reliable focal mechanics.

Despite the differences in the maximum earthquake, $M_{\mathrm{w}}=6.9$ in the case of Perez et al. (2014) and $M_{\mathrm{w}}=6.6$ 6.7 in our work, the range of PGA values are similar. In addition, the largest PGA expected in both studies reaches up to $0.7 \mathrm{~g}$, a large number that confirms the potential hazards in the near-field of the SRF. This is similar to the faults that caused the Chūetsu and Northridge earthquakes. 


\subsection{Seismic hazard zoning}

Based on the characteristic earthquake definition, we present the PGA response associated with the SRF in Fig. 10 (described in detail in Sect. 4.7). To determine the expected damage, we need appropriate fragility curves for the study zone and the corresponding building typology, which are not available. Alternatively, we have the chance to compare the expected acceleration with the reported effects of the Maule 2010 earthquake $\left(M_{\mathrm{w}}=8.8\right)$ in Chile. This megathrust event generated $0.56 \mathrm{~g}$ of PGA in a district of the city with a low shear velocity (Barrientos, 2010). The acceleration of the Maule event, and the expected acceleration in the SRF are both shown in Fig. 10. Accelerometers that recorded the largest PGA values during the Maule 2010 earthquake coincide with reported damages in homes and building collapses nearby. Equivalent damages are observed in the northern Santiago district, where site effects associated with low shear wave velocity soils induced large PGA responses. However, in this case instrumental acceleration records are not available. Despite the scarce data support, we assume a deterministic approach, where $0.56 \mathrm{~g}$ PGA can cause construction collapse. Under the assumption of a fault displacement, segments of the hanging wall side of the SRF filled with sediments have an extremely high risk (PGA in the range of 0.5 to $0.8 \mathrm{~g}$ ). In Chile the construction norm does not consider the existence of crustal faults, and the PGA estimated for building design in Santiago is $0.3 \mathrm{~g}$, based only on the occurrence of subduction earthquakes without site effects. This acceleration estimate is fulfilled in the majority of subduction earthquakes. The Maule 2010 earthquake effects represent a good example of such behavior (Fig. 10), and consequently, the associated building damage in $0.3 \mathrm{~g}$-zones was minor. Therefore, the sectors of the Santiago Basin with expected acceleration higher than $0.3 \mathrm{~g}$ in the San Ramón PGA map involve a moderate risk. Finally, the possible surface rupture of the SRF implies the highest collapse risk because the constructions are made to resist no more than $1 \%$ of differential settlements (Skempton and Macdonald, 1956), meaning, at most $0.5 \mathrm{~m}$ in a $50 \mathrm{~m}$ wide building. This number is widely exceeded by the expected $1-4 \mathrm{~m}$ of average slip. In addition, TEM and gravity evidences suggest that surface ruptures are not always breaking the surface in the same place (Figs. 3b and 5). Therefore, the possible surface rupture zone is an area and not the mapped fault-trace line on the surface.
The extremely high risk zones of the area (hanging wall filled with sediments) are located to the east of segments 2 and 4 (Fig. 10). The hanging wall of segment 2 is almost completely urbanized now, mainly with houses of one or two floors, with better resistance than the buildings given their larger rigidity. The other extremely high risk zone on the hanging wall of segment 4 has few constructions and until 2015 was mostly a low-density urbanized zone. Given this scenario, a successful mitigation measure must limit the building construction in these areas or at least not allow unreinforced masonry buildings. In addition, the norm must prohibit building in the proximity of the surface rupture zone, with special emphasis on public buildings, like hospitals or schools, and industrial buildings that may cause major damage, such as gas stations or nuclear research plants.

\section{Conclusions}

Natural seismicity registered in a 1-year local network is compatible with SRF activity. However, stress release as seismic activity along the SRF is secondary compared to the activity observed in other sectors near Santiago.

Geophysical and geomorphological evidences suggest that the SRF is segmented into four subfaults that are most likely activated independently. Under this scenario a characteristic earthquake of magnitude $M_{\mathrm{W}}=6.2-6.7$ is expected.

Based on the TEM imaging, Apoquindo hill outcrops, and seismic evidence, the SRF is a high-angle structure.

If the SRF is activated, it can produce building collapse; therefore, it is necessary to take preventative actions to avoid catastrophic damages. In particular, construction in the rupture zone must be highly restricted, and construction of unreinforced masonry buildings in hanging walls filled with sediments must be limited.

The integrated methodology applied in this study provides a valuable tool to estimate the seismic risk associated with crustal faults with low slip rate and subtle surface evidences.

\section{Data availability}

The data sets "gravity database" and "seismic database" are available in the Supplement material. 
Appendix A: Abbreviations and units

San Ramón Fault

Peak ground acceleration

Stream gradient index

Sinuosity index

Shear wave velocity of the first $30 \mathrm{~m}$
SRF -

PGA [g] amount of gravity $\left(9.8 \mathrm{~m} \mathrm{~s}^{-1}\right)$

SL [undimensional]

SI [undimensional]

$V_{\mathrm{S} 30} \quad\left[\mathrm{~m} \mathrm{~s}^{-1}\right]$ 


\section{The Supplement related to this article is available online at doi:10.5194/nhess-16-2511-2016-supplement.}

Acknowledgements. We want to thank the important field support provided by A. Mella, A. Bosh, N. Moraga, G. Sielfeld, I. Santibañez, B. Perez, S. Pérez, R. Figueroa, and M. Lizama. T. García kindly provided field support as well as her expertise in geophysical software. We thank G. Cassasa and A. Yañez for providing their homes to install a seismic station for over a year, and ENERGÍA ANDINA for providing their seismometers. CG5 gravimeter was provided by CEGA, FONDAP-CONICYT project no. 15090013. TEM experiment was partially supported by Fondecyt project no. 1141139. DICTUC S. A and CIGIDEN (FONDAP-CONICYT project no. 15110017) provided economic support for the development of this work. We also thank R. Rauld and G. Vargas for improving the quality of the paper with their discussion and precise comments. Finally, we appreciate the discussions with G. Arancibia, J. Cembrano, T. Roquer, and all of the emerging Geosciences group at PUC.

Edited by: B. D. Malamud

Reviewed by: R. Rauld and G. Vargas Easton

\section{References}

Aki, K. and Richards, P. G.: Quantitative Seismology: Theory and Methods, New York, W. H. Freeman, 1-699, 1980.

Ambraseys, N. N., Douglas, J., Sarma, S. K., and Smit, P. M.: Equations for the estimation of strong ground motions from shallow crustal earthquakes using data from Europe and the middle east: Horizontal peak ground acceleration and spectral acceleration, B. Earthq. Eng., 3, 1-53, 2005.

Anderson, E. M.: The Dynamics of Faulting and Dyke Formation with Applications to Britain, Hafner Pub. Co., 1-206, 1951.

Armijo, R., Rauld, R., Thiele, R., Vargas, G., Campos, J., Lacassin, R., and Kausel, E.: The West Andean Thrust, the San Ramón Fault, and the seismic hazard for Santiago, Chile, Tectonics, 29, TC2007, 1-34, 2010.

Barrientos, S. E.: Terremoto $(M=8.8)$ del 27 de febrero de 2010 en Chile, Revista de La Asociacion Geologica Argentina, 67, 412420, 2010.

Blaser, L., Kruger, F., Ohrnberger, M., and Scherbaum, F.: Scaling Relations of Earthquake Source Parameter Estimates with Special Focus on Subduction Environment, B. Seismol. Soc. Am., 100, 2914-2926, 2010.

Bosch, A.: Profundidad del basamento de la cuenca de Santiago a través de un modelo de gravimetría y evaluación de su potencial geotérmico, Engineering Thesis, Pontificia Universidad Católica de Chile, 2015.

Bull, W. B. and McFadden, L. D.: Tectonic geomorphology north and south of the Garlock fault, California, in: Geomorphology in Arid Regions: Binghamton, edited by: Doehring, D. O., 115138, 1977.

Burbank, D. W. and Anderson, R. S.: Tectonic Geomorphology: Second Edition. Blackwell Science, Oxford, UK, 159-200, 2001.
Carretier, S., Ritz, J. F., Jackson, J., and Bayasgalan, A.: Morphological dating of cumulative reverse fault scarps: Examples from the Gurvan Bogd fault system, Mongolia, Geophys. J. Int., 148, 256-277, 2002.

Casa, A. L., Cortés, J. M., and Borgnia, M. M.: Pleistocene evidences of deformation in the La Carrera fault system $\left(32^{\circ} 40^{\prime}-\right.$ $\left.33^{\circ} 15^{\prime} \mathrm{LS}\right)$, Cordillera Frontal of Mendoza, Revista de La Asociación Geológica Argentina, 67, 91-104, 2010.

Charrier, R., Baeza, O., Elgueta, S., Flynn, J. J., Gans, P., Kay, S. M., Muñoz, N., Wyss, A. R., and Zurita, E.: Evidence for Cenozoic extensional basin development and tectonic inversion south of the flat-slab segment, southern Central Andes, Chile $\left(33^{\circ}\right.$ $36^{\circ}$ S.L.), J. S. Am. Earth Sci., 15, 117-139, 2002.

Chen, Y.-G., Chen, W.-S., Lee, J.-C., Lee, Y.-H., Lee, C.-T., Chang, H.-C., and Lo, C.-H.: Surface rupture of 1999 Chi-Chi earthquake yields insights on active tectonics of central Taiwan, B. Seismol. Soc. Am., 91, 977-985, 2001.

Chiou, B. S. J. and Youngs, R. R.: NGA Model for Average Horizontal Component of Peak Ground Motion and Response Spectra. Pacific Engineering Research Center Report, 1-94, 2008.

Chiou, B. S. J. and Youngs, R. R.: Update of the Chiou and Youngs NGA Ground Motion Model for Average Horizontal Component of Peak Ground Motion and Response Spectra, Earthq. Spectra, 30, 1117-1153, 2014.

Crone, A., Machette, M., and Bowman, J. R.: Geologic investigations of the 1988 Tennant Creek, Australia, Earthquakes - Implications for Paleoseismicity in Stable Continental Regions, edited by: US Geological Survey, Washington, United States government printing office, A6-A11, 1989.

Cultrera, G., Ameri, G., Saraò, A., Cirella, A., and Emolo, A.: Ground-motion simulations within ShakeMap methodology: application to the 2008 Iwate-Miyagi Nairiku (Japan) and $1980 \mathrm{Ir}-$ pinia (Italy) earthquakes, Geophys. J. Int., 193, 220-237, 2013.

Farías, M., Charrier, R., Carretier, S., Martinod, J., Fock, A., Campbell, D., Cáceres, J., and Comte, D.: Late Miocene high and rapid surface uplift and its erosional response in the Andes of central Chile $\left(33^{\circ}-35^{\circ} \mathrm{S}\right)$, Tectonics, 27, 1-22, 2008.

Farr, T. G. et al.: The Shuttle Radar Topography Mission, Rev. Geophys., 45, RG2004, doi:10.1029/2005RG000183TS, 2007.

Fernández, J. C.: Repuesta sísmica de la cuenca de Santiago, Región Metropolitana de Santiago, Carta Geológica de Chile: Serie Geología Ambiental, 2003.

Font, M., Amorese, D., and Lagarde, J.-L.: DEM and GIS analysis of the stream gradient index to evaluate effects of tectonics: The Normandy intraplate area (NW France), Geomorphology, 119, 172-180, 2010.

Godoy, E., Yañez, G., and Vera, E.: Inversion of an Oligoncene volcano-tectonic basin and uplift of its superimposed Miocene magmatic arc, Chilean central Andes: First seismic and gravity evidence, Tectonophysics, 306, 217-236, 1999.

Hack, J. T.: Studies of Longitudinal Stream Profiles in Virginia and Maryland, US Geological Survey Professional Paper 294-B, p. 97, 1957.

Hack, J. T.: Stream-profile analysis and stream-gradient index, J. Res. US Geol. Surv., 1, 421-429, 1973.

Hank, T. C. and Kanamori, H.: A Moment Magnitude Scale, J. Geophys. Res., 84, 2348-2350, 1979. 
Jain, S. and Verma, P. K.: Mapping of active tectonics intensity zones using remote sensing and GIS, J. Indian Soc. Remote Sens., 34, 131-142, 2006.

Kissling, E.: Program VELEST USER'S GUIDE - Short introduction. Technical report, Institute of Geophysics, ETH Zurich, Zurich, Switzerland, 1995.

Klein, F.: Users guide to HYPOINVERSE, a program for Vax and PC350 computers to solve for earthquake locations, open file report 84-000, USGS, 1984.

Kurtz, A. C., Kay, S. M., Charrier, R., and Farrar, E.: Geochronology of Miocene plutons and exhumation history of the El Teniente region, central Chile $\left(34^{\circ}-35^{\circ} \mathrm{S}\right)$, Rev. Geol. Chile, 24, 75-90, 1997.

Leyton, F.: Zonificación sísmica de la cuenca de Santiago, Chile, X Congreso Chileno de Sismología E Ingeniería Antisísmica, Antofagasta, Chile, 1-5, 2010.

Leyton, F., Pérez, A., Campos, J., Rauld, R., and Kausel, E.: Anomalous seismicity in the lower crust of the Santiago Basin, Chile, Phys. Earth Planet. Int., 175, 17-25, 2009.

Machette, M., Crone, A., and Bowman, R. J.: Geologic investigations of the 1986 Marryat Creek, Australia, earthquake: implications for paleoseismicity in stable continental regions, USGS Bulletin, Report B 2, B1-B28, 1993.

Merritts, D. and Vincent, K. R.: Geomorphic response of coastal streams to low, intermediate, and high rates of uplift, Mendocino triple junction region, northern California, Geol. Soc. Am. Bull., 101, 1373-1388, 1989.

Mori, J. and Somerville, P.: Seismology and Strong Ground Motions in the 2004 Niigata Ken Chuetsu, Japan, Earthquake, Earthq. Spectra, 22, S9-S21, 2006.

Moore, J. R., Sanders, J. W., Dietrich, W. E., and Glaser, S. D.: Influence of rock mass strength on the erosion rate of alpine cliffs, Earth Surf. Process., 34, 16-25, 2009.

Mpodozis, C. and Ramos, V.: The Andes of Chile and Argentina, Geology of the Andes and its Relation to Hydrocabron and Mineral Resourses, 11, 59-90, 1989.

Pérez, A., Ruiz, J., Vargas, G., Rauld, R., Rebolledo, S., and Campos, J.: Improving seismotectonics and seismic hazard assessment along the San Ramón Fault at the eastern border of Santiago city, Chile, Nat. Hazards, 71, 243-274, 2014.

Porcella, R., Etheredge, E., Maley, R., and Acosta, V.: Accelerograms recorded at USGS national strong-motion network station during the $M_{\mathrm{S}}=6.6$ Northrige, California earthquake of January 17, 1994, Open file report 94-141, US Geological survey, 1994.

Rauld, R.: Deformación cortical y peligro sísmico asociado a la falla San Ramón en el frente cordillerano de Santiago, Chile Central $\left(33^{\circ} \mathrm{S}\right)$, Ph.D. thesis, Universidad de Chile, 2011.

Rauld, R., Vargas, G., Armijo, R., Ormeño, A., Valderas, C., and Campos, J.: Cuantificación de escarpes de falla y deformación reciente en el frente cordillerano de Santiago, in: X Congreso Geológico Chileno, Antofagasta, Chile, 2006.

Sadigh, K., Chang, C.-Y., Egan, J. A., Makdisi, F., and Youngs, R. R.: Attenuation Relationships for Shallow Crustal Earthquakes Based on California Strong Motion Data, Seismol. Res. Lett., 68, 180-189, 1997.

Scawthorn, C. and Rathje, E. M.: The 2004 Niigata Ken Chuetsu, Japan, Earthquake, Earthq. Spectra, 22, 1-8, 2006.
Schwartz, D. P. and Coppersmith, K. J.: Fault behavior and characteristic earthquakes - examples form the Wasatch and SanAndreas fault zones, J. Geophys. Res., 89, 5681-5698, 1984.

Singh, V. and Tandon, S. K.: Evidence and con-sequences of tilting of two alluvial fans in the Pinjaur dun, Northwestern Himalayan Foothills, Quat. International, 159, 21-31, 2007.

Skempton, A. W. and Macdonald, D. H.: The Allowable Settlement of Buildings, Proceedings of the Institution of Civil Engineering of London, Part 3, 727-784, 1956.

Stern, C., Amini, H., Charrier, R., Godoy, E., Hervé, F., and Varela, J.: Petrochemistry and age of rhyolitic pyroclastic flows which occur along the drainage valleys of rhe Río Cachapoal (Chile) and the Río Yaucha and Río Papagayos (Argentina), Rev. Geol. Chile, 23, 39-52, 1984.

Stock, J. D. and Montgomery, D. R.: Geologic constraints on bedrock river incision using the stream power law, J. Geophys Res., 104, 4983-4993, 1999.

Telford, W. M., Geldart, L. P., and Sheriff, R. E.: Applied Geophysics, Cambridge University Press, UK, 1-770, 1990.

Thiele, R.: Hoja de Santiago, Región Metropolitana, Carta Geológica de Chile, 39, 51, Servicio Nacional de Geología y Minería City, Santiago, 1980.

USGS (United States Geological Survey), available at: http://earthquake.usgs.gov/earthquakes/eventpage/us20002926\# impact (last access: 3 November 2016), 2015.

USGS (United States Geological Survey), available at: http://earthquake.usgs.gov/earthquakes/world/events/1985_ 01_26.php, last access: 3 November 2016.

Vargas, G., Klinger, Y., Rockwell, T. K., Forman, S. L., Rebolledo, S., Baize, S., Lacassin, R., and Armijo, R.: Probing large intraplate earthquakes at the west flank of the Andes, Geology, 42, 1083-1086, 2014.

Villegas, L.: Estructura sismica cortical en los andes centrales $\left(33^{\circ}\right.$ $34.5^{\circ} \mathrm{S}$ ): concentraciones de sismicidad bajo minas el teniente y disputada, Ph.D. thesis, Universidad de Chile, 2012.

Wells, S. G., Bullard, T. F., Menges, C. M., Drake, P. G., Karas, P. A., Kelson, K. I., Ritter, J. B., and Wesling, J. R.: Regional variations in tectonic geomorphology along a segmented convergent plate boundary, Pacific coast of Costa Rica, Geomorphology, 1, 239-265, 1988.

Wells, D. L. and Coppersmith, K. J.: New Empirical Relationships among Magnitude, Rupture Length, Rupture Width, Rupture Area, and Surface Displacement, B. Seismol. Soc. Am., 84, 974-1002, 1994.

Wesnousky, S. G.: Displacement and geometrical characteristics of earthquake surface ruptures: Issues and implications for seismichazard analysis and the process of earthquake rupture, B. Seismol. Soc. Am., 98, 1609-1632, 2008.

Yañez, G., Muñoz, M., Flores-Aqueveque, V., and Bosch, A.: Gravity derived depth to basement in Santiago Basin, Chile: implications for its geological evolution, hydrogeology, low enthalpy geothermal, soil characterization and geo-hazards, Andean Geol., 42, 147-172, 2015.

Yielding, G., Jackson, J. A., King, G. C. P., Sinvhal, H., Vita-Finzi, C., and Wood, R. M.: Relations between surface deformation, fault geometry, seismicity, and rupture characteristics during the El Asnam (Algeria) earthquake of 10 October 1980, Earth Planet. Sc. Lett., 56, 287-304, 1981. 
Youngs, R. R., Chiou, S.-J., Silva, W. J., and Humphrey, J. R.: Strong Ground Motion Attenuation Relationships for Subduction Zone Earthquakes, Seismol. Res. Lett., 68, 58-73, 1997. 